\title{
PROFIL LEVEL KEMAMPUAN METAKOGNITIF MAHASISWA BERINDEKS PRESTASI (IP) TINGGI DALAM PEMECAHAN MASALAH JUMPING TASK DITINJAU DARI TINGKATAN SEMESTER DI STKIP PGRI SITUBONDO
}

\author{
Zainul Munawwir \\ STKIP PGRI Situbondo, Indonesia \\ e-mail: sinollonis@gmail.com
}

\begin{abstract}
Abstrak: This research aims to describe the profile of the metacognitive abilities level of Mathematics Education Department students, STKIP PGRI Situbondo with a high semester achievement index in jumping task problem-solving. This research is classified as descriptive research using a qualitative approach. The research subjects were 3 students, i.e semester II, IV, and VI based on the highest semester achievement index in the class. The data were obtained by the Jumping Task (JT) test on the topic of arithmetic sequences and series and semi-structured interviews with time triangulation which were analyzed using the flow of data reduction, data presentation, and conclusions. The results of data analysis show that the levels of metacognitive abilities between the three research subjects are quite different even though their semester achievement indices are relatively similar. The level difference is not directly proportional to the semester level. In other words, the higher the semester level is not a determinant of the higher the metacognitive level.
\end{abstract}

Keywords: Metacognitive abilities level, jumping task problem-solving, high semester achievement index

\begin{abstract}
Abstrak: Penelitian ini bertujuan untuk mendeskripsikan profil jenjang kemampuan metakognitif mahasiswa program studi pendidikan matematika semester II, IV, dan VI di STKIP PGRI Situbondo semester genap 2019/2020 dengan indeks prestasi semester (IPS) tinggi dalam pemecahan masalah jumping task. Penelitian ini tergolong menjadi penelitian deskriptif dengan menggunakan pendekatan kualitatif. Subjek penelitian dalam penelitian ini yaitu mahasiswa program studi pendidikan matematika sebanyak 3 mahasiswa yang terdiri dari 1 mahasiswa semester II, IV, dan VI berdasarkan IPS tertinggi di kelasnya. Data dalam penelitian ini diperoleh dengan cara tes Jumping Task (JT) topik barisan dan deret aritmatika dan wawancara semi terstruktur dengan triangulasi waktu yang kemudian dianalisis dengan alur reduksi data, penyajian data, dan penarikan kesimpulan. Hasil analisis data menunjukkan kesimpulan bahwa jenjang kemampuan metakognitif antara ketiga subjek penelitian cukup berbeda meskipun indeks prestasinya relatif sama. Perbedaan jenjang atau level tersebut tidak berbanding lurus dengan tingkatan semesternya. Dengan kata lain, semakin tinggi tingkatan semester bukan penentu semakin tingginya level metakognitif.
\end{abstract}

Kata Kunci: Level kemampuan metakognisi, pemecahan masalah jumping task, indeks prestasi semester

\section{PENDAHULUAN}

Kemampuan kognitif setiap orang terus berkembang melalui proses pendidikan dan juga dipengaruhi oleh perkembangan fisik terutama otaknya. Suatu situasi atau masalah juga merupakan faktor penentu perkembangan kemampuan 
kognitif seseorang. Dengan dihadapkan pada situasi atau permasalahan tertentu, seseorang akan dirangsang untuk merespon kemampuan kognitifnya untuk menyelesaikan permasalahan tersebut.

Dalam matematika, masalah yang sifatnya menantang dan tergolong masalah atau soal tingkat tinggi, penyelesainnya membutuhkan usaha yang lebih keras dalam berfikir, terlebih lagi jika masalah atau soal tersebut tergolong di atas tuntutan kurikulum, sehingga seseorang harus ekstra keras dalam berpikir dan memaksimalkan aktifitas kognisinya. Masalah-masalah menantang tersebut yang levelnya di atas tuntutan kurikulum disebut sebagai Jumping task (Hobri, Oktavianingtyas, et al., 2020) dan cukup efektif untuk meningkatkan kemampuan berpikir seseorang/mahasiswa. Sejalan dengan pendapat tersebut, Hobri, et al., (2020) dan Putri dan Zulkardi (2019) mengatakan bahwa suatu masalah Jumping task dapat mengembangkan kemampuan berpikir siswa atau mahasiswa. Kemampuan berpikir mahasiswa, khususnya terkait dengan kemampuan kognisi salah satunya dapat dilihat dari capaian indeks prestasinya (Patmawati et al., 2019). Indeks prestasi (IP) dapat menggambarkan prestasi akademik yang dicapai oleh setiap mahasiswa.

Dalam menyelesaikan suatu permasalahan, aspek kognitif tidak dapat secara begitu saja berjalan dengan sendirinya, melainkan perlu pengaturan dan pengendalian sehingga ketika seseorang menggunakan kemampuan kognisinya, maka diperlukan kesadaran untuk menetukan dan mengatur aktifitas kognitif apa yang hendak digunakan. Penggambaran proses mental kesadaran dalam mengatur dan mengendalikan kemampuan kognitif ini disebut dengan metakognitif (Iskandar, 2014; Khairati et al., 2016; Yuwono \& Wijayanti, 2018). Dengan demikian pengetahuan metakognitif dapat diartikan sebagai pengetahuan tentang kognisi secara umum serta kesadaran dan pengetahuan tentang kognisi diri sendiri.

Dalam kenyataannya, kesadaran akan pengendalian dan pengaturan aktifitas kognitif setiap orang tidaklah sama. Hal inilah yang menyebabkan tingkat kedalaman setiap orang dalam memproses semua informasi ketika menyelesaikan suatu masalah berbeda-beda. Dengan pengendalian aktifitas kognitif, seseorang akan tahu tentang pencapaian pemahaman dan proses mengingat akan sesuatu, 
sedangkan melalui pengaturan aktifitas kognitif seseorang dapat merencanakan, mengarahkan, dan mengevaluasi aktifitas kognitifnya sendiri.

Dengan mengevaluasi proses kognitifnya sendiri, seseorang akan tahu sejauh mana tingkat kemajuannya dalam memahami sesuatu. Misalnya ketika seseorang mahasiswa gelisah pada saat tidak mengerti penjelasan yang diberikan oleh dosennya, misalnya topik atau suatu konsep dalam matematika, hal itu berarti kecemasan mahasiswa tersebut menggambarkan seberapa buruknya ia dalam mengolah informasi yang dijelaskan sehingga timbul perasaan gelisah karena gagal memahami apa yang dianggap penting bagi dirinya. Proses metakognitif selanjutnya yang dapat ditempuh oleh mahasiswa yaitu apa yang dapat mahasiswa lakukan ketika mengalami hal tersebut. Bentuk proses ini tentunya berbeda setiap orang atau mahasiswa karena berkaitan dengan proses mental dan kesadarannya sendiri.

Beberapa tahun terakhir, beberapa peneliti mengutarakan temuannya berupa penjenjangan kemampuan metakognitif. Laurens (2010) telah memvalidasi sistem penjenjangan kemampuan metakognitif menjadi 6 jenjang atau level. Keenam jenjang tersebut yaitu Jenjang Tacit Use, Jenjang Aware Use, Jenjang Semistrategic Use, Jenjang Strategic Use, Jenjang Semireflective Use dan Jenjang Reflective Use. Sedikit berbeda dengan pendapat tersebut, Nugraheni et al., (2018) menyimpulkan bahwa penjenjangan kemampuan metakognitif seseorang terdiri dari 4 jenjang yaitu jenjang atau level Tacit Use, jenjang Aware Use, jenjang Strategic Use, dan jenjang Reflective Use. Dari kedua pendapat tersebut, pendapat dari Laurens (2010) dirasa lebih baik oleh peneliti karena penjenjangannya lebih lengkap dan mendetail karena memperhalus antar beberapa jenjang, misalnya antara jenjang Aware Use dan jenjang Strategic Use ditambah jenjang Semistrategic Use sehingga pendapat tersebut digunakan peneliti dalam penelitian ini.

Beberapa penelitian sebelumnya terkait dengan indeks prestasi dan kemampuan metakognisi mahasiswa sebagian besar hanya terbatas pada satu angkatan pada suatu semester. Jarang sekali penelitian yang menerobos batas angkatan sehingga penelitian yang tidak membatasi hanya pada satu angkatan atau jenjang tertentu menjadi menarik untuk diteliti. Dari penjabaran tersebut maka peneliti tertarik untuk meneliti tentang "Profil Level Metakognitif Mahasiswa 
Dengan Indeks Prestasi Semester (IPS) Tinggi Dalam Pemecahan Masalah Jumping Task Ditinjau Dari Tingkatan Semester di STKIP PGRI Situbondo.

\section{METODE}

Penelitian ini tergolong menjadi penelitian deskriptif dengan menggunakan pendekatan kualitatif karena penelitian menggunakan latar alamiah, yaitu peneliti masuk langsung pada lingkungan alamiah subjek penelitian dan tidak ada perlakuan khusus pada subjek penelitian serta instrumen utama dalam penelitian ini adalah peneliti sendiri. Subjek penelitian (SP) dalam penelitian ini yaitu mahasiswa program studi pendidikan matematika sebanyak 3 mahasiswa yang terdiri dari 1 mahasiswa semester II (SP2), IV (SP4), dan VI (SP6). Pemilihan 3 subjek penelitian tersebut berdasarkan IPS (Indeks Prestasi Semester) tertinggi di kelasnya. Data dalam penelitian ini diperoleh dengan cara tes Jumping Task (JT) topik barisan dan deret aritmatika dan wawancara semi terstruktur dengan triangulasi waktu yang kemudian dianalisis dengan alur reduksi data, penyajian data, dan penarikan kesimpulan.

\section{HASIL DAN PEMBAHASAN}

\section{HASIL}

Data Subjek Penelitian

Pemilihan subjek penelitian ini diawalai dengan konsultasi dengan pihak operator yang mengelola daftar nilai dan indeks prestasi mahasiswa di STKIP PGRI Situbondo dengan cara melihat data indeks prestasi mahasiswa program studi pendidikan matematika semester genap 2019/2020. Dari data tersebut kemudian dipilih 3 mahasiswa yang memiliki indeks prestasi tertinggi di kelasnya. Data tersebut dapat dilihat pada Tabel 1 .

Tabel 1. Data Subjek Penelitian (SP)

\begin{tabular}{ccccc}
\hline NO & NAMA & NIM & SEMESTER & IPS \\
\hline $\mathbf{1}$ & SP2 & 2019030163 & II & 3,67 \\
\hline $\mathbf{2}$ & SP4 & 2018030157 & IV & 4,00 \\
\hline $\mathbf{3}$ & SP6 & 2017030147 & VI & 3,93 \\
\hline
\end{tabular}

Mahasiswa semester VIII tidak dipilih karena mereka sibuk dengan tugas akhir/skripsi. 


\section{Hasil penelitian}

Hasil analisis data pada penelitian ini berdasarkan tahapan pemecahan masalah Polya (1973) yaitu tahap memahami masalah, tahap membuat rencana pemecahan masalah, tahap melaksanakan rencana pemecahan masalah, dan tahap memeriksa kembali hasil pemecahan masalah. Untuk mendapatkan data yang valid, peneliti melakukan triangulasi waktu sehingga pelaksanaan JT1 dan JT2 (sekaligus wawancara) dilakukan dalam rentang waktu 1 minggu.

a) SP2

Pada tahap memahami masalah JT (Jumping Task) 1, SP2 mencoba memahami masalah dengan cara membaca masalah dengan seksama dengan cepat, tetapi diulang berkali-kali. SP2 terlihat kurang yakin terhadap pemahamnnya pada masalah JT1. Hal itu terlihat ketika ditanya oleh peneliti, SP2 menjawab dengan jawaban yang ragu-ragu dan kurang meyakinkan. SP2 menyebutkan dengan cukup lengkap apa saja informasi yang diketahui dari masalah JT1 tetapi tidak dapat menjelaskan makna dari beberapa informasi yang diperoleh. Penjelasan yang dilakukan oleh SP2 cenderung acak dengan kalimat yang tidak jelas dan penuh dengan kata-kata ambigu dan terlihat kebingungan. Hal ini tidak jauh berbeda dengan pelaksanaan JT2. Pola-pola kebingungan yang dilakukan SP2 juga terjadi saat JT2. Baik pada JT1 ataupun JT2, SP2 ketika ditanya pemahamannya oleh peneliti tidak langsung menjawab, melainkan membaca lagi permasalahan pada soal.

Tahapan pemecahan masalah selanjutnya yaitu tahap membuat rencana pemecahan masalah. Pada tahap ini, SP2 kesulitan menyusun strategi pemecahan masalah. SP2 menjelaskan dengan bahasa yang sulit dipahami bahkan tidak bermakna dan cenderung tidak sistematis. Ketika ditanya mengapa rencana itu dipilih, SP2 tidak dapat menjelaskan dengan baik alasannya.

Pada tahapan pelaksanaan rencana penyelesaian masalah, SP2 melaksanakan sesuai rencana yang telah dijelaskan sebelumnya, tetapi mengalami kesulitan karena ketidakpahamannya terhadap konteks permasalahan pada JT1. SP2 menuliskan penyelesiannya dengan tidak sistematis dan tidak bermakna, terlihat memaksakan dirinya agar tetap ada 
penyelesaian meskipun tidak efektif. Hal ini terlihat pada jawaban SP2 pada lembar penyelesaian yang ditulisnya yaitu pada Gambar 1 .

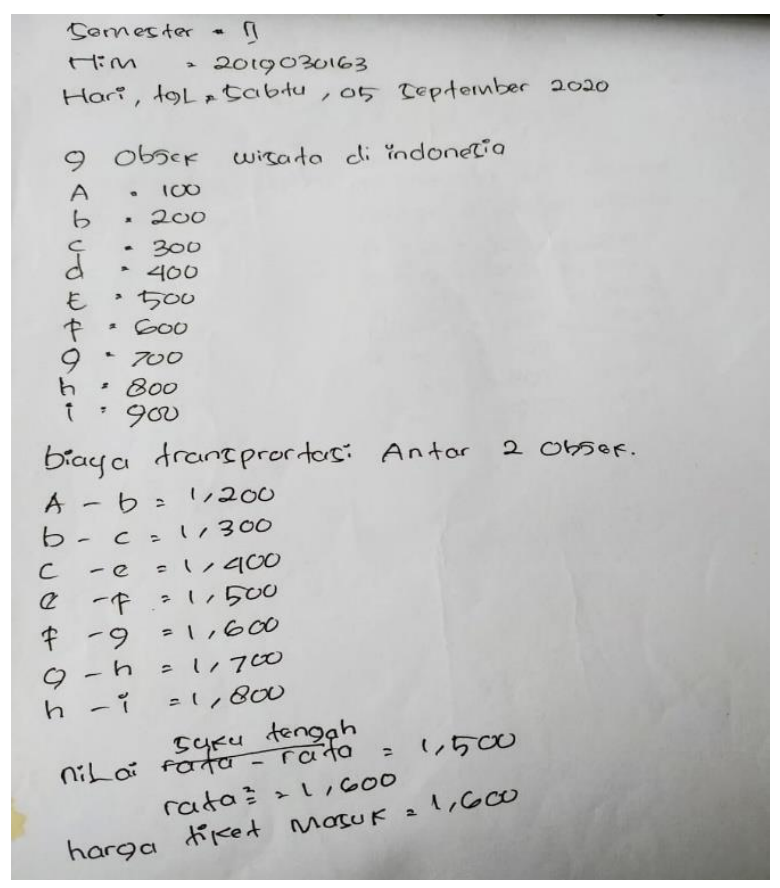

Gambar 1. Jawaban SP2 pada JT1

Untuk melihat kemampuan evaluasinya, sesuai tahapan terakhir pemecahan masalah, peneliti menanyakan kepada SP2 apakah sudah yakin dengan penyelesaian yang dibuatnya. SP2 menjelaskan bahwa dia kurang bisa memahami JT1 maupun JT2 sehingga tidak dapat mencapai jawaban akhir, sesuai dengan yang diinginkan JT1 dan JT2, karena tidak tahu apa yang harus dilakukan selanjutnya. SP2 tidak bisa menemukan letak kesalahannya pada proses penyelesaian masalah yang ditulisnya.

b) $\mathrm{SP} 4$

Untuk memahami masalah pada JT1 dan JT2, SP4 menggunakan cara yang sama yaitu membaca berulang-ulang masalah pada soal tersebut. SP4 dengan cukup percaya diri mengatakan bahwa dia paham terhadap maksud pada JT1 maupun JT2. SP4 cukup mendetail menjelaskan tentang informasi-informasi yang diperoleh dari JT1 dan JT2. SP4 tidak terlalu kaku membayangkan masalah pada JT1, dan itu terulang pada JT2, khususnya ketika memisalkan harga masing-masing objek wisatanya. SP4 berhasil memahami maksud dari setiap informasi yang diperoleh. Hal itu diperjelas ketika peneliti mencoba 
menjebaknya dengan pertanyaan yang menggiring pada kesalahan pemahaman, dan ternyata tidak berhasil menyesatkan SP4.

Meskipun berbekal pemahaman yang cukup baik, SP4 merasa tidak terlalu yakin dapat menyelesaikan masalah pada JT1 mupun JT2. Untuk memperoleh rencana penyesaian, SP4 mencoba membaca kembali permasalahan pada soal untuk merangkai informasi-informasi yang ada untuk mencapai jawaban yang diinginkan permasalahan tersebut. Setelah memperoleh gambaran yang jelas, SP4 merasa cukup yakin apa langkah-langkah yang akan dilakukan.

Setelah berhasil menjelaskan kepada peneliti tentang rencana penyelesaian pemecahan masalah yang akan dilakukan, SP4 kemudian melaksanakan rencana tersebut. Pada proses penyelesaian, SP4 terlihat mencoba berbagai cara untuk menyelesaikan permasalahan, baik pada JT1 maupun pada JT2. Hal ini dapat dilihat pada Gambar 2 hingga Gambar 5.

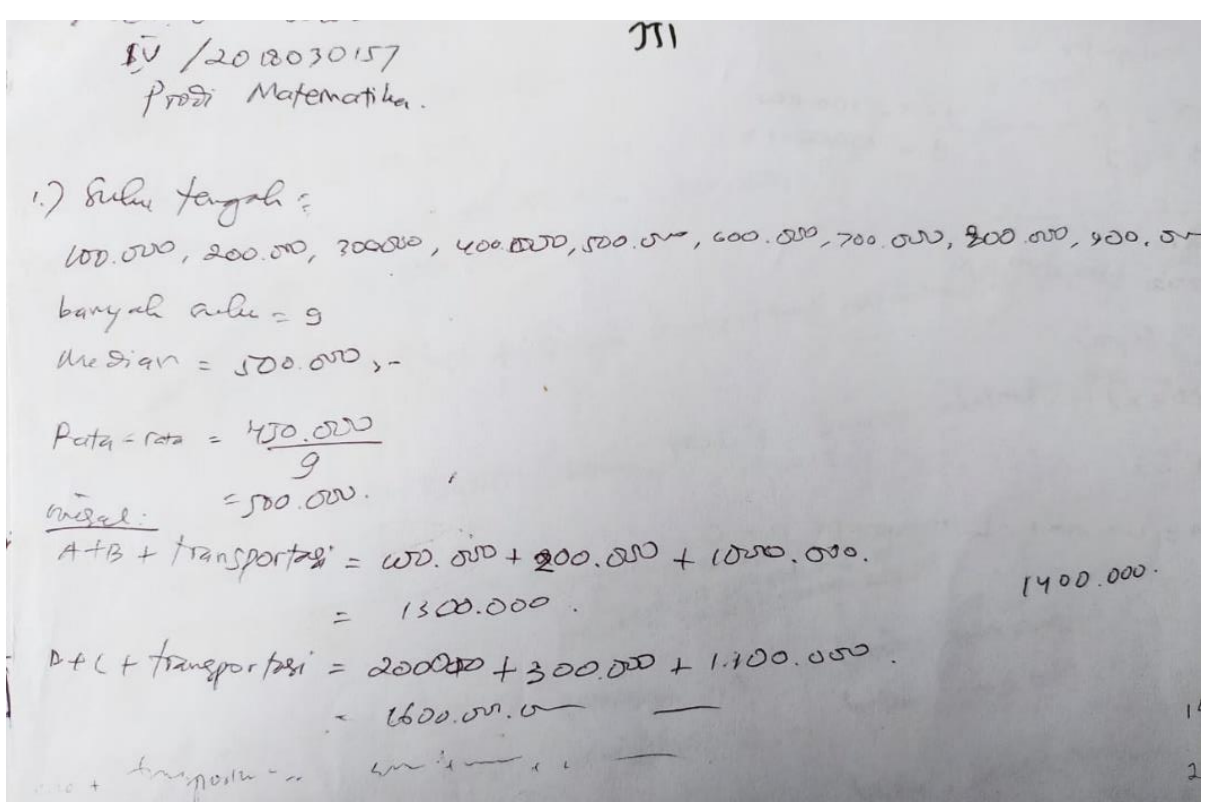

Gambar 2. Cara pertama yang dilakukan SP4 


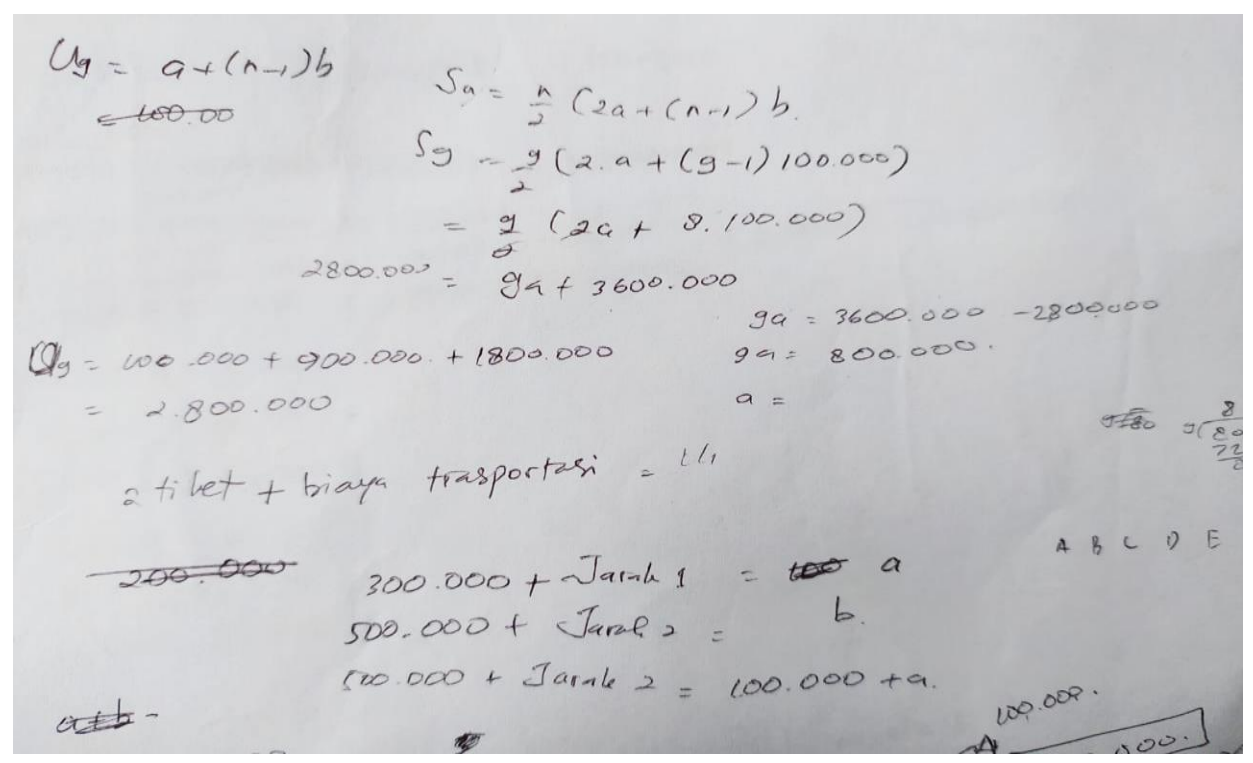

Gambar 3. Cara kedua yang dilakukan SP4

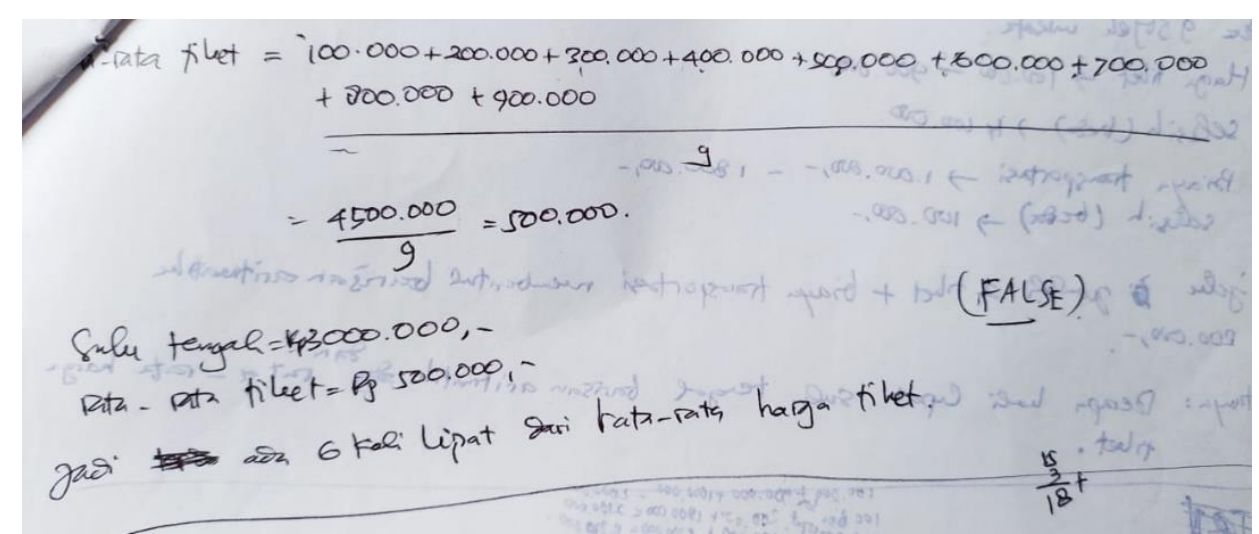

Gambar 4. Cara ketiga yang dilakukan SP4

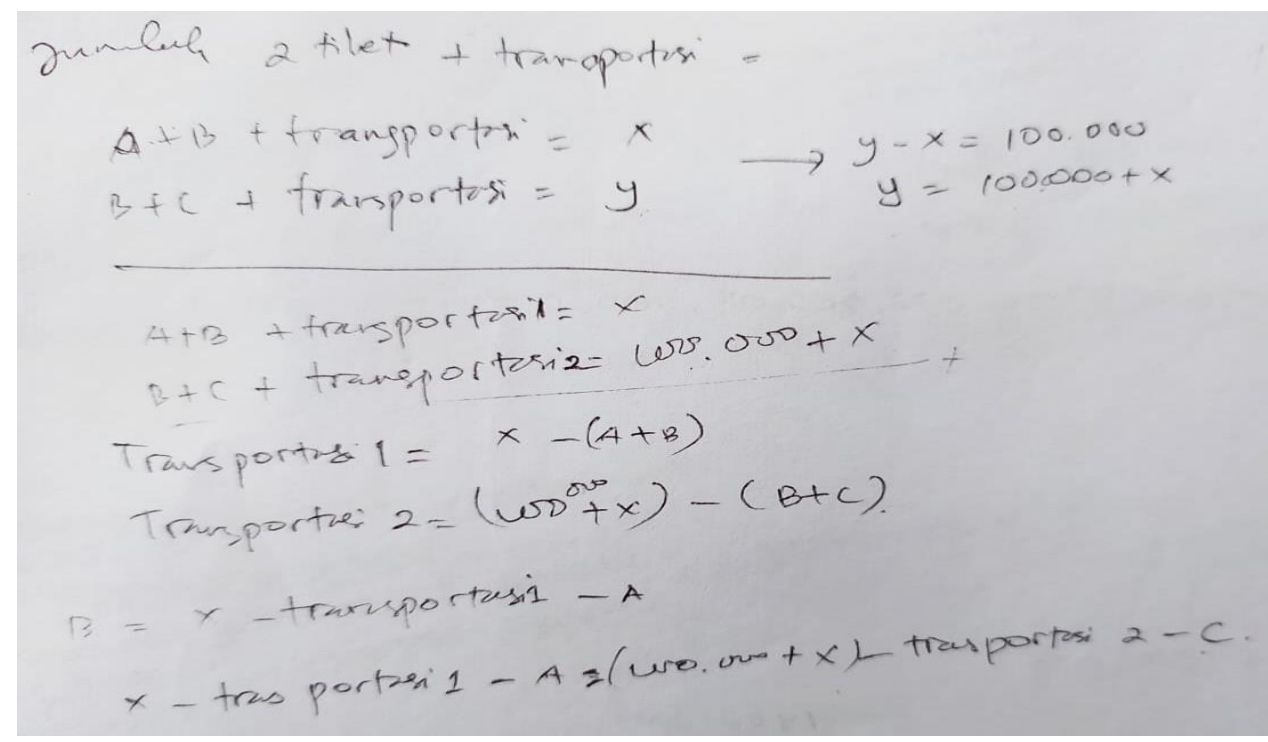

Gambar 5. Cara keempat yang dilakukan SP4 
Berbagai cara ini dilakukan oleh SP4 karena belum berhasil mencari jawaban yang diinginkan permasalahan. Ada sekitar 6 cara yang dilakukan SP4, terapi tetap belum berhasil menemukan atau memecahkan masalah baik JT1 maupun JT2.

Ketika ditanya oleh peneliti terkait berbagai cara yang dilakukan SP4, SP4 menjelaskan bahwa selalu menghasilkan barisan yang tidak sesuai dengan yang diinginkan masalah. SP4 sadar dan mengetahui kesulitan dan ketidak mampuannya untuk menemukan barisan yang diminta soal.

c) SP6

Tahapan awal pemecahan masalah yaitu tahap memahami masalah. SP6 mencoba memahami masalah pada JT1 dan JT2 dengan cara yang sama yaitu membaca berulang-ulang masalah dan mengatakan kepada peneliti bahwa SP6 paham terhadap masalah pada JT tersebut. Ketika ditanya oleh peneliti, SP6 tidak secara utuh menjelaskan, melainkan terputus-putus sembari membaca kembali masalah di JT1 dan JT2. SP6 berhasil memilah informasi yang diketahui dan apa yang ditanyakan pada JT1 dan JT2. Ketika menyebutkan informasi yang diperoleh, SP6 langsung menjelaskan maksud dari informasi tersebut dengan cukup mendetail menggunakan bahasanya sendiri. SP6 juga tidak terkecoh ketika digiring pada pemahaman yang salah oleh peneliti.

Meskipun pemahaman SP6 cukup baik terhadap permasalahan pada JT1 maupun JT2, tetapi SP6 merasa tidak yakin untuk memecahkan masalah tersebut, bahkan pada JT1, SP6 mengatakan bahwa dia tidak dapat menyelesaikan masalah tersebut. Tetapi ketika mencoba membaca kembali, kemudian dengan ragu-ragu SP6 mengatakan akan mencoba terlebih dahulu. SP6 menjelaskan apa yang akan dilaksanakan dengan cukup logis langkahlangkah yang akan dilaksanakan.

Pada tahapan pelaksanaan rencana pemecahan masalah, SP6 terlihat cukup konsisten dengan rencana awal yang dijelaskan kepada peneliti, baik pada JT1 maupun JT2. Penyelesaian SP6 pada JT1 dan JT 2 dapat dilihat pada Gambar 6 dan 7. 


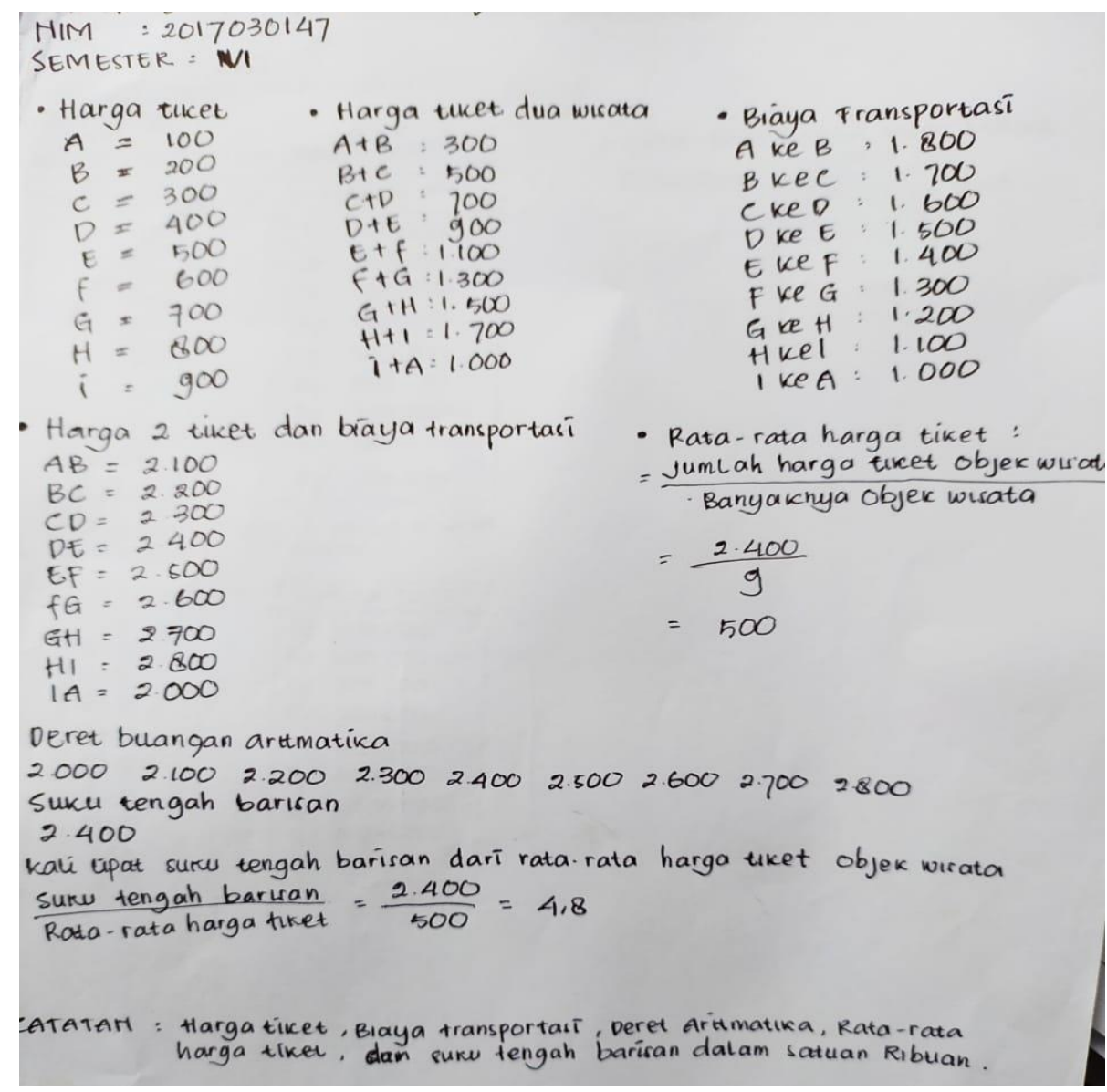

Gambar 6. Penyelesaian masalah JT1 oleh SP6

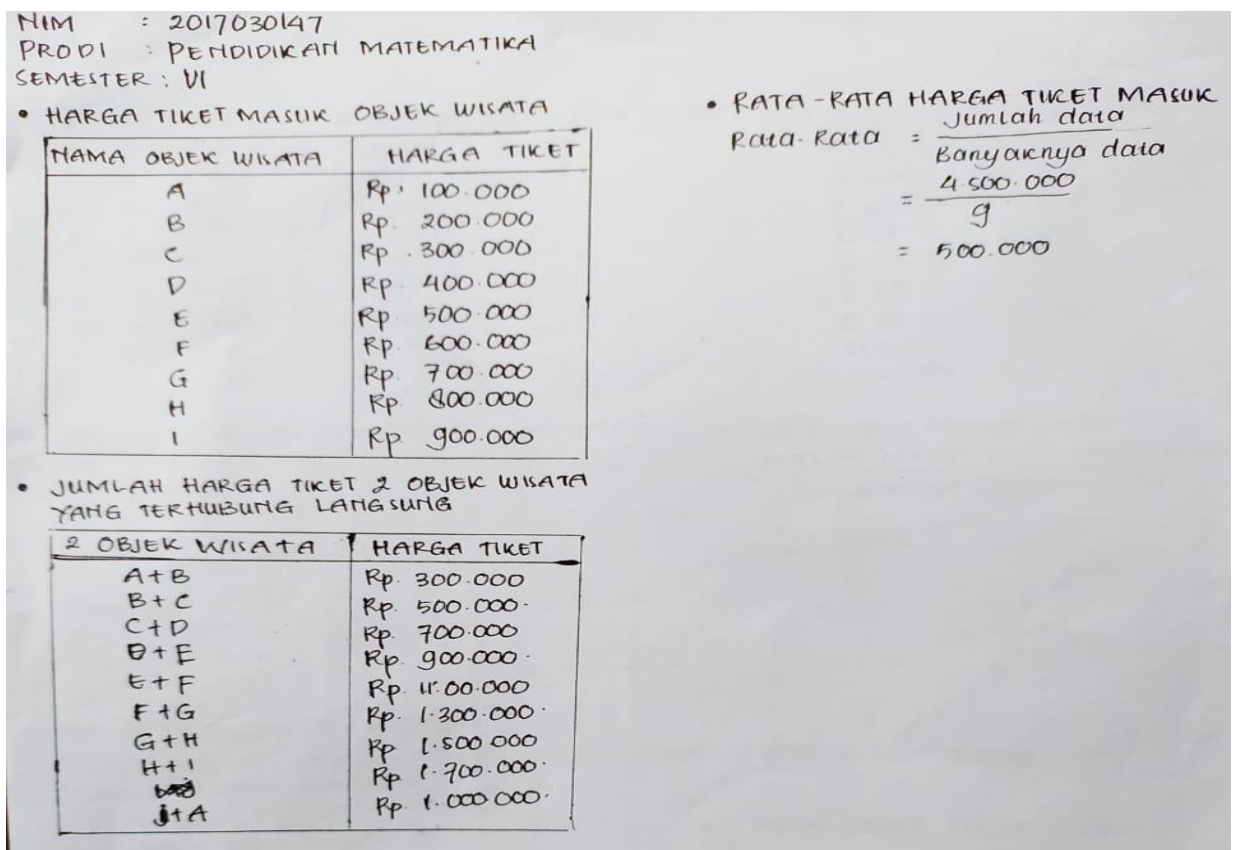

Gambar 7. Penyelesaian masalah JT2 oleh SP6 
Berdasarkan Gambar 6 dan Gambar 7, terlihat bahwa SP6 mencoba menggunakan cara yang sama antara JT1 dan JT2, tetapi karena konteksnya sedikit berbeda, maka cara tersebut tidak efektif. SP2 tidak berhasil menemukan hal yang salah pada jawaban JT1, merasa cukup yakin atas penyelesaian tersebut.

\section{PEMBAHASAN}

a) SP2

Pada tahap memahami masalah, SP2 menjelaskan kepada peneliti dengan bahasa yang sulit dipahami. Terlihat bahwa SP2 kesulitan untuk mengkomunikasikan pemahamannya. Kalimat yang digunakan oleh SP2 dalam menjelaskan terputus-putus dan terkadang menjawab dengan jawaban yang bukan jawaban yang sebenarnya diinginkan oleh suau pertanyaan. Hal itu diperjelas dengan tulisan jawaban SP2 dalam memecahkan JT1 dan JT2.

Dari hal itu, salah satu indikator level tacit used cocok dengan yang terjadi pada SP2. Hal ini sejalan dengan Laurens (2010), Sophianingtyas dan Sugiarto (2013), dan Nugraheni, et al., (2018) yang mengatakan bahwa seseorang yang level metakognisinya adalah level Tacit Used adalah seseorang yang pemahamannya tidak mudah dikomunikasikan karena sulit untuk diekspresikan sehingga orang yang menjadi lawan bicaranya juga kesulitan untuk memahaminya. Tetapi ini baru anggapan awal peneliti dan belum dapat disimpulkan level metakognisi dari SP2. Untuk dapat menyimpulkan level metakognisi dari SP2, maka harus dicermati kesesuaian SP2 terhadap indikatorindikator lainnya.

Fenomena tersebut tidak menandakan bahwa SP2 sama sekali tidak memahami suatu konteks permasalahan, ada hal-hal tertentu yang masuk akal dari penjelasan SP2 terkait SP2 menentukan suku tengah dari barisan bilangannya adalah 1500. SP2 menjelaskan bahwa penentuan tersebut karena nila 1500 berada "di antara" 1200 dan 1800. Kata di antara sengaja peneliti tulis dengan tanda kutip karena mungkin maksud dari SP2 adalah pas di tengahtengah. Hal itu termasuk hal yang cukup masuk akal atau logis secara matematis. Hal ini menandakan bahwa SP2 kesulitan mengkomunikasikan pemahamannya tetapi yang perlu digaris bawahi yaitu SP2 sadar atas keputusan 
yang diambilnya, dan ini termasuk salah satu indikator level aware used (Laurens, 2010) yaitu mengambil suatu keputusan yang dilatarbelakangi suatu alasan tertentu yang merupakan level di atas tacit used.

Indikator lain dari level aware used yaitu mengalami kebingungan ketika membaca masalah. Dari awal ketika berusaha memahami masalah, SP2 memang terlihat kebingungan untuk memahami masalah pada JT1 dan JT2 yang ditandai dengan caranya untuk memahami masalah tersebut yaitu dengan membaca berkali-kali. SP2 juga menyadari bahwa ketidakmampuannya dalam menyelesaikan masalah JT ataupun memahami maksud dari setiap informasi yang ada pada JT. Hal itu menjelaskan bahwa SP2 sebenarnya memahami maksud dari JT, tetapi dengan ketidakmampuannya memahami beberapa konsep terkait masalah tersebut menyebabkan SP2 tidak dapat merancang rencana yang efektif untuk memecahkan masalah tersebut.

Dari beberapa penjelasan tersebut terlihat bahwa SP2 seakan akan berada pada tahap tacit used karena kesulitan untuk mengkomunikasikan atau menejelaskan pemahamannya kepada peneliti. Tetapi hal itu terbantahkan ketika SP2 memiliki cukup kesadaran bahwa setiap keputusan yang diambil didasarkan pada alasan tertentu yang cukup logis. Selain itu adanya kesadaran terhadap kelemahan dan ketidakmanpuannya dalam memecahkan masalah semakin membuktikan bahwa level metakognisi SP2 tidak berada pada tacit used, melainkan pada level aware used. Siswa dengan level metakognitif aware use mampu memahami masalah tetapi tidak dapat menuliskan prosedur pemecahan masalah yang sesuai dan bahkan tidak melakukan evaluasi (Zakiah, 2020).

b) $\mathrm{SP} 4$

Temuan yang cukup berbeda dari SP2 diperoleh oleh peneliti pada SP4. SP4 terlihat sangat cukup meyakinkan ketika menjelaskan baik dari pemahamannya maupun ketika menjelaskan rencana pemecahan masalah yang akan dilakukan. Penjelasan yang dilakukan oleh SP4 menggunakan bahasa yang sederhana dan mudah dimengerti, dan cukup sistematis. Berdasarkan hal itu maka dapat dibantahkan jika dikatakan bahwa SP4 berada pada level tacit used. 
Selain hal tersebut, SP4 juga dengan sangat jelas menjelaskan alasannya ketika menentukan sesuatu, misalnya alasannya mengenai penentuan rencana pemecahan masalah. SP4 sangat sadar tentang pengetahuannya mengenai konsep-konsep apa saja yang dipakai. Meskipun sesekali menampakkan kebingungan, SP4 berhasil mencerna atau memahami masalah dengan membaca kembali permasalahan JT tersebut.

Dengan menjelaskan dengan cukup baik rencana penyelesaian atau pemecahan masalah pada JT menandakan bahwa SP4 sadar bahwa ada cara untuk menyelesaikan masalah tersebut. Kesadaran ini menandakan bahwa SP4 telah melewati level aware use dan berada pada level Semistrategic Use (Nugraheni et al., 2018; Sophianingtyas \& Sugiarto, 2013).

Ketika melaksanakan rencana penyelesaian, SP4 terlihat meggunakan berbagai cara. Ketika menyadari bahwa cara pertama tidak efektif, SP4 segera mengolah kembali proses berpikirnya dan segera menggunakan cara lainnya yang dianggap masuk akal. Cara kedua ternyata juga tidak efektif dan segera menggunakan cara lainnya. Begitu seterusnya hingga cara terakhir sebelum SP4 menyerah. Hal ini menandakan bahwa SP4 berada pada level strategic use. Hal ini sesuai dengan pendapat Laurens (2010), Sophianingtyas dan Sugiarto (2013), dan Nugraheni, et al., (2018) yang mengatakan bahwa salah satu indikator stategic use yaitu menggunakan strategi yang memunculkan kesadaran. SP2 juga memiliki cara untuk meyakinkan apa yang dilakukan dengan cara memberikan argumen logis yang mendukung pemikirannya. Hal ini ditandai ketika pemilihan cara yang digunakan, meskupun dalam hal ini SP4 tetap tidak berhasil menemukan penyelesaian yang efektif sehingga tidak dapat dikatakann bahwa SP4 memiliki level metakognisi semireflective maupun reflective use. Hal ini sejalan dengan pernyataan Laurens (2010), Sophianingtyas dan Sugiarto (2013), dan Nugraheni, et al., (2018) yang mengatakan bahwa seseorang yang level metakognisinya semireflektif use ataupun di atasnya yaitu dapat menyelesaikan atau memecahkan masalah secara menyeluruh dengan efektif. Dengan kata lain level metakognisi SP4 yaitu di bawah level semireflective use yaitu strategic use.

c) SP6 
Pemecahan masalah pada tahap memahami masalah, SP6 memahami masalah dengan cara yang hampir sama dengan SP2 maupun SP4 yaitu membaca berulang-ulang masalah pada JT, baik pada JT1 maupun JT2. SP6 menjelaskan dengan cukup meyakinkan menggunakan bahasa yang mudah dipahami dan logis. Hal ini menandakan SP6 sadar akan pengetahuannya yang dibuktikan dengan tidak terpengaruhnya SP6 ketika digiring pada pemahaman yang salah. Sampai tahap ini SP6 telah menunjukkan bahwa dia tidak pada level tacit use. Laurens (2010) dalam penelitiannya mengatakan bahwa level metakognisi tacit use umumnya tidak dapat menjelaskan pemahamannya dengan baik atau dengan kata lain penjelasannya tidak atau sulit untuk dimengerti karena terputus-putus dan tidak sistematis.

Ketika melaksanakan rencana pemecahan masalah, SP6 cukup konsisten dengan rencana awal yang disampaikan kepada peneliti. Pada JT1, SP6 menyelesaikan masalah pada JT1 hingga akhir. Ketika ditanya oleh peneliti mengapa menggunakan cara tersebut, SP6 cukup logis menjelaskan kepada peneliti. Dari hal ini SP6 memenuhi semua indikator pada level aware use. Hal ini sesuai dengan penelitian Laurens (2010), Sophianingtyas dan Sugiarto (2013), dan Nugraheni, et al., (2018) yang menjelaskan bahwa ketika seseorang atau siswa sadar akan pemahamannya dan cukup baik dalam menjelaskan pemahamannya tersebut menggunakan bahasa yang mudah dimengerti, maka siswa atau seseorang tersebut memenuhi level metakognitif aware use.

Untuk lebih jelas melihat kemampuan maksimal atau level maksimal dari metakognisi SP6, perlu ditelusuri apakah SP6 juga memenuhi beberapa indikator dari level di atas aware use. Pada JT1, sebenarnya terdapat kesalahan yang dilakukan oleh SP6 tetapi meskipun SP6 melakukan pengecekan terhadap hasil penyelesaian, SP6 tetap tidak dapat melihat kesalahan tersebut. SP6 hanya fokus pada jawaban akhir.

Ketidaksadaran SP6 terhadap kesalahan tersebut ternyata konsisten dia coba lakukan kembali di JT2. Pada saat JT2 barulah SP6 menyadari bahwa pemecahan masalah yang dilakukan pada JT2 dan JT1 salah. Kesalahan tersebut baru SP6 sadari karena cara tersebut tidak dapat diaplikasikan pada JT2. SP6 mencoba berpikir ulang dan mengolah pemahamannya untuk mencari cara lain. 
Hal ini dibuktikan dari pernyataan SP6 ketika kebingungan untuk mencari cara lain, SP6 mengatakan dengan spontanitas bahwa dia akan mencari cara lain, tetapi pada akhirnya SP6 tidak berhasil memecahkan masalah tersebut karena alasan yang logis yaitu tidak menemukan cara lain untuk menemukan barisan bilangan yang dimaksud oleh masalah pada JT karena hal itu merupakan kunci untuk menyelesaikan JT.

Dari hal tersebut yang perlu kita garis bawahi yaitu SP6 cukup sadar bahwa terpadat penyelesaian pada JT tetapi dari kesalahan yang dilakukannya, SP6 menunjukkan kebingungan dan tidak menemukan cara untuk memperbaikinya. Hal ini jelas bahwa SP6 telah berada pada level metakognisi semistrategic use dan belum strategic use. Sejalan dengan penelitian yang dilakukan oleh Sophianingtyas dan Sugiarto (2013) yang menjelaskan bahwa level strategic used akan terpenuhi jika seseorang dapat mengorganisasi pemikirannya dengan menyadari strategi-strategi khusus untuk mengatasi masalah dengan tepat.

\section{SIMPULAN}

Penelitian ini menghasilkan profil level metakognisi mahasiswa dengan Indeks Prestasi Semester (IPS) tinggi dalam pemecahan masalah jumping task ditinjau dari tingkatan semester di STKIP PGRI Situbondo. Pada serangkaian tahap pemecahan masalah JT (Jumping Task), mahasiswa semester 2 dengan IPS tinggi level metakognisinya yaitu aware use dengan kemampuan komunikasi yang rendah sehingga kesulitan dalam menjelaskan pemahamannya, memahami masalah tetapi tidak dapat mengolah data dengan baik, serta mengambil suatu keputusan yang dilatarbelakangi suatu alasan tertentu.

Mahasiswa semester 4 dan 6 dengan IPS tinggi memiliki level metakognisi yang juga berbeda. Mahasiswa semester 6 dengan IPS tinggi sadar dengan kemampuannya, sadar bahwa terdapat penyelesaian, sadar juga bahwa terdapat kesalahan tetapi tidak dapat menemukan cara bagaimana untuk memperbaikinya, hanya berpikir keras memahami kembali masalah tanpa mencoba menuliskan cara lain sehingga level metakognisi tertinggi pada mahasiswa tersebut yaitu semistrategic use. Sedangkan mahasiswa semester 4 dengan IPS tinggi memiliki level metakognisi lebih tinggi dari mahasiswa semester 6, yaitu level metakognisi strategic use. Hal ini karena mahasiswa tersebut selalu mengecek pemikirannya, 
dan ketika menemukan kesalahan, maka segera merevisi dengan mencoba-coba rencana lain yang dianggap lebih masuk akal dari cara pertama. Hal ini terus dilakukan oleh mahasiswa semester 4 tersebut hingga muncul 6 strategi.

Dari kesimpulan tersebut, cukup membuat peneliti terkejut karena sedikit berbeda dari dugaan awal. Peneliti menduga bahwa semakin tinggi tingkatan semester, maka kemampuan atau level metakognisinya juga semakin tinggi. Hal ini menunjukkan bahwa tingkatan semester tidak dapat dijadikan tolak ukur dari tingginya level metakognisi mahasiswa. Hal ini mungkin karena beberapa faktor lain yang tidak diperhatikan oleh peneliti, misalnya sikap positif mahasiswa terhadap matematika (disposisi matematis) yang mempengaruhi terhadap minat dan semangat juang untuk memecahkan masalah matematika dan faktor internal atau eksternal lainnya. Untuk penelitian selanjutnya terkait penelitian ini agar peneliti memperhatikan faktor-faktor lain tersebut sehingga didapat hasil penelitian yang lebih komprehensif.

\section{UCAPAN TERIMAKASIH}

Penelitian ini dilakukan peneliti tidak dengan tanpa sumbangsi orang atau pihak-pihak lain, antara lain lembaga STKIP PGRI Situbondo sendiri yang telah memberikan kemudahan terkait dokumen perizinan untuk melaksanakan penelitian di lembaga tersebut. Selain itu kemudahan dari operator dalam memberikan datadata pendukung terkait penelitian juga memudahkan peneliti dalam melaksanakan penelitian. Dengan demikian, peneliti mengucapkan terimakasih kepada pihakpihak yang telah membantu jalannya penelitian ini.

\section{DAFTAR RUJUKAN}

Hobri, H., Tussolikha, D., \& Oktavianingtyas, E. (2020). Pemecahan Masalah dalam Menyelesaikan Soal Jumping Task ditinjau dari Gaya Kognitif. Jurnal Elemen. https://doi.org/10.29408/jel.v6i2.1987

Hobri, Oktavianingtyas, R., Trapsilasiwi, D., Murtikusuma, R. P., \& A'Yun, Q. (2020). Analysis of students' critical thinking skills on social arithmetics with jumping task. Journal of Physics: Conference Series, 1465(1). https://doi.org/10.1088/1742-6596/1465/1/012070

Hobri, Widyasari, N. K., \& Murtikusuma, R. P. (2020). Analisis Pemecahan Masalah Siswa SMA dalam Menyelesaikan Masalah Jumping Task pada Materi Barisan dan Deret Aritmetika. Math Didactic: Jurnal Pendidikan Matematika. 6(2) 124-141. https://doi.org/10.33654/math.v6i2.952

Iskandar, S. M. (2014). Pendekatan Keterampilan Metakognitif Dalam 
Pembelajaran Sains Di Kelas. Erudio Journal of Educational Innovation, 2(2), 13-20. https://doi.org/10.18551/erudio.2-2.3

Khairati, I. A., Feranie, S., \& Karim, S. (2016). Penerapan Strategi Metakognisi pada Cooperative Learning untuk Mengetahui Profil Metakognisi dan Peningkatan Prestasi Belajar Siswa SMA pada Materi Fluida Statis. Jurnal Penelitian \& Pengembangan Pendidikan Fisika, 2(1), 65-72. https://doi.org/10.21009/1.02110

Laurens, T. (2010). Penjenjangan Metakognisi Siswa Yang Valid Dan Reliabilitas. Jurnal Pendidikan Dan Pembelajaran Universitas Negeri Malang, 17(2), 201-211.

Nugraheni, L., Budayasa, I. K., \& Suwarsono, S. T. (2018). A Metacognitive Profile of Vocational High School Student's Field Independent in Mathematical Problem Solving. Journal of Physics: Conference Series, 947(1). https://doi.org/10.1088/1742-6596/947/1/012066

Patmawati, K., Puspitasari, N., Mutmainah, S. N., \& Prayitno, B. E. (2019). Profil Kemampuan Berfikir Kreatif Ditinjau Dari Kemampuan Akademik Mahasiswa. Edu Sains Jurnal Pendidikan Sains \& Matematika, 7(2), 11-18. https://doi.org/10.23971/eds.v7i2.1386

Putri, R. I. I., \& Zulkardi, Z. (2019). Designing Jumping Task on Percent using PMRI and Collaborative Learning. International Journal on Emerging Mathematics Education. https://doi.org/10.12928/ijeme.v3i1.12208

Sophianingtyas, F., \& Sugiarto, B. (2013). Identifikasi Level Metakognitif dalam Memecahkan Masalah Materi Perhitungan Kimia. UNESA Journal of Chemical Education, 2(1), 21-27.

Yuwono, M. R., \& Wijayanti, S. (2018). Profil Metakognisi Mahasiswa Perempuan Dalam Memecahkan Masalah Geometri Analitik Ditinjau Dari Gaya Kognitif. Seminar Nasional Pendidikan Matematika Ahmad Dahlan 2018, 1973, 108117.

Zakiah, N. E. (2020). Level kemampuan metakognitif siswa dalam peLevel kemampuan metakognitif siswa dalam pembelajaran matematika berdasarkan gaya kognitifmbelajaran matematika berdasarkan gaya kognitif. Jurnal Riset Pendidikan Matematika, 7(2), 132-147. 